\title{
PENGEMBANGAN KREATIVITAS ANAK USIA DINI DALAM KELUARGA
}

\author{
Peny Husna Handayani, Apiek Gandamana, dan Farihah* \\ Surel: peny_husna@unimed.ac.id
}

\begin{abstract}
Early age is an important time for the development of one's creativity. Creativity is necessary in the development of children because it will affect the work of the right brain and left brain. Creativity is a necessity in the present and also in the future. Creativity is needed to pick up the century of competition because developing individual creativity can produce innovative work or something new that is needed by the times. Family is the first and foremost teacher in child development. In educating children to grow into a creative person parents should accompany children in the growth period.
\end{abstract}

Keywords: creativity, early childhood, family

\section{PENDAHULUAN}

$\mathrm{K}$

reativitas merupakan komponen individu dan dahulu. Tumbuhnya kreativitas dapat dicapai melalui lingkungan keluarga dan sekolah. Anak memerlukan lingkungan yang kondusif untuk dapat mengembangkan bakat (intelegensi, kreativitas, dan motivasi) dan kemampuannya secara ${ }^{1}$ optimal untuk dapat mewujudkan dirinya sesuai dengan kebutuhan pribadinya dan kebutuhan masyarakat.

Kreativitas sangat diperlukan dalam perkembangan anak karena akan mempengaruhi kerja otak kanan

\footnotetext{
"Peny Husna Handayani, S.Pd., M.Pd., Dosen Prodi PG PAUD FIP UNIMED *Apiek Gandamana, S.Pd., M.Pd, Dosen Jurusan PGSD FIP UNIMED *Dr. Farihah, M.Pd Dosen Jurusan PKK FT UNIMED
}

dan otak kiri. Penelitian yang telah dilakukan oleh Munandar (1985, 1999), Semiawan (2002, 2003), Clack (1988), dan Beaty (1996) dalam Masnipal (2013; 229) mengungkapkan bahwa rentang usia dini merupakan masa penting untuk pengembangan kreativitas seseorang. Lingkungan belajar anak usia dini dapat mempengaruhi penampilan perkembangan kemampuan berpikir kreatif anak (Clifford, 1988, Hammond, 1990 dalam Masnipal, 2013; 220).

Lestari (2006; 20) menyatakan bahwa pengembangan kreativitas sejalan dengan pengembangan kepribadian anak. Jika kreativitas anak berkembang dengan baik, maka anak akan mengalami perkembangan kepribadian yang sehat. Anak akan 
dapat mengembangkan kepribadian yang mandiri, percaya diri, dan produktif. Sebaliknya, jika kreativitas anak kurang dapat berkembang dengan baik, maka anak akan mengalami pertumbuhan kepribadian yang tergantung, kurang percaya diri, mudah putus asa, tidak memiliki keberanian dan tidak produktif.

Kreativitas adalah kebutuhan di masa kini dan juga masa yang akan datang. Kreativitas sangat diperlukan untuk menjemput abad persaingan karena pengembangkan kreativitas individu dapat menghasilkan karya inovatif atau sesuatu yang baru yang dibutuhkan oleh zaman (Suroso, 2002; 168).

Keluarga merupakan lingkungan yang pertama kali anak kenal sebelum mengenal lingkungan lainnya, seperti lingkungan sekolah dan masyarakat, maka keluarga merupakan guru pertama dan utama dalam perkembangan anak. Dalam mendidik anak agar tumbuh menjadi orang yang kreatif orang tua harus mendampingi anak dalam masa tumbuh kembangnya. Tidak dapat dipungkiri jika peran orang tua sangat penting bagi kehidupan anak. Ayah dan Ibu harus memiliki peran serta yang seimbang agar anak dapat tumbuh kreatif.

Penelitian Miller dan Gerard (1979) menyatakan bahwa terdapat hubungan yang positif antara karakteristik latar belakang keluarga dengan kreativitas anak-anak. Orang tua dengan anak-anak yang kreatif cenderung membangun rasa hormat dan kebebasan antara mereka dan anak-anaknya sejak dini. Kreativitas anak tidak dipengaruhi gender/jenis kelamin. Oleh karena itu, orang tua bias melakukan pengembangan kreatvitas di rumah tanpa membedakan antara anak laki-laki maupun perempuan. Hal ini sejalan dengan pernyataan Rothenberg (2015) bahwa keluarga memiliki peranan yang sangat penting dalam pengembangan anak kreatif. Anak-anak yang tumbuh dalam keluarga yang membantu pengembangan kreativitas akan tumbuh menjadi orang dewasa dengan ketekunan yang ekstrem, motivasi yang luar biasa untuk bekerja dan mengeksplorasi, keberanian untuk mengambil resiko, yang semuanya merupakan karakteristik orang kreatif di berbagai bidang.

Semua keluarga memiliki peluang yang sama dalam mendidik kreativitas anak-anaknya dalam keluarga. Rothenberg (2015) menemukan bahwa dalam banyak kasus kemiskinan, kurang berpendidikan, mengungsi, atau orang tua peraih nobel, anak kreatif bias saja muncul, karena kreatif dibuat, bukan dilahirkan.

\section{PEMBAHASAN}

\section{Pengertian dan Pentingnya Kreativitas}

Kreativitas adalah sebuah komponen yang dengannya kita berhadapan dengan masalah dan tantangan dalam kehidupan didunia ini. Kreativitas biasanya berkaitan dengan bakat untuk menciptakan sesuatu yang 
imajinatif. Menurut Penguin Dictionary Of Psychology (Suryana, 2004:23) mengungkapkan bahwa definisi kreatif yaitu proses mental yang menghasilkan solusi, ide, konseptualisasi, bentuk artistik, teori atau produk yang baru atau unik.

Munandar (2009:1) menjelaskan bahwa Keberbakatan (giftedness) dan keunggulan dalam kinerja mempersyaratkan dimilikinya tiga tandan (cluster) ciri-ciri yang kait mengait yaitu kemampuan umum atau kecerdasan diatas rata-rata, kreatifitas dan pengikatan diri terhadap tugas sebagai motivasi internal yang cukup tinggi. Oleh karena itu untuk menumbuhkan sumberdaya manusia yang berkualitas, ketiga karakteristik tersebut perlu ditumbuhkembangkan dalam tida lingkungan pendidikan : keluarga, sekolah dan masyarakat.

Coleman \& Hammen (Munandar, 1999) mengungkapkan, ada tiga faktor yang secara umum dapat ikut menunjang cara berpikir kreatif, yaitu:

1. Kemampuan kognitif. Seseorang harus mempunyai kecerdasan tinggi. Ia harus secara terusmenerus mengembangkan intelektualitasnya.

2. Sikap terbuka. Cara berpikir kreatif akan tumbuh apabila seseorang bersikap terbuka pada stimulus internal dan eksternal. Sikap terbuka dapat dikembangkan dengan memperluas minat dan wawasan.

3. Sikap bebas, otonom, dan percaya diri. Berpikir secara kreatif membutuhkan kebebasan dalam berpikir dan berekspresi. Juga memerlukan kemandirian berpikir, tidak terikat pada otoritas dan konvensi sosial yang ada. Yang terpenting, ia percaya pada kemampuan dirinya.

Untuk mengidentifikasi kreativitas berpikir yang dimiliki oleh individu, Munandar(1999) mengungkapkan kreativitas berhubungan dengan ciri-ciri aptitude dan non aptitude.

1. Ciri-ciri kemampuan berpikir kreatif (aptitude) meliputi :

a. Ketrampilan berpikir lancar (fluency) : kemampuan mengemukakan berbagai macam gagasan, selalu memberikan banyak cara / saran untuk melakukan banyak hal dan selalu memikirkan lebih dari satu jawaban.

Indikator kelancaran (fluency): 1) mengajukan banyak pertanyaan, 2) bekerja lebih cepat dan melakukan lebih banyak daripada anak-anak lain, 3) lancar dalam mengemukakan sejumlah jawaban secara cepat dan tepat atas suatu permasalahan, 4) dapat dengan cepat melihat kesalahan dan kelemahan pada suatu objek situasi, 5) lancar mengungkapkan gagasannya dalam menyelesaikan suatu masalah, 6) lancar dalam mengungkapkan sejumlah cara atau saran untuk melakukan berbagai hal.

b. Ketrampilan berpikir luwes (flexibility) : kemampuan 
menghasilkan gagasan, jawaban atau pertanyaan yang bervariasi, dapat melihat masalah dari banyak alternative atau arah yang berbeda-beda dan mampu mgeubah cara pendekatan atau pemikiran.

Indikator keluwesan (flexibility): 1) memberikan aneka ragam penguatan yang tidak lazim terhadap suatu objek, 2) memberikan macam-macam penafsiran (interpretasi) terhadap suatu gambar, cerita atau masalah. 3) menerapkan suatu konsep atau asa dengan cara yang berbeda-beda, memberikan pertimbangan terhadap suatu situasi, yang berbeda dari yang diberikan orang lain, 5) dalam membahas atau mendiskusikan suatu situasi selalu mempunyai posisi yang berbeda atau bertentangan dari mayoritas kelompok, 6) jika diberikan masalah biasanya memikirkan macam-macam cara yang berbeda-beda untuk menyelesaikannya, menggolongkan hal-hal menurut pembagian (kategori) yang berbeda-beda, 8) mampu mengubah arah berpikir secara spontan.

c. Ketrampilan memperinci (elaboration) : kemampuan untuk memperkaya dan mengembangkan gagasan serta memperinci detil-detil dari suatu objek atau situasi sehingga lebih menarik.
Indikator

kerincian

(elaboration): 1) mencari arti yang lebih mendalam terhadap jawaban atau pemecahan masalah dengan melakukan langkah-langkah yang terperinci, 2) mengembangkan atau memperkaya gagasan-gagasan orang lain, 3) mencoba atau menguji detil-detil untuk melihat arah yang akan ditempuh, 4) mempunyai rasa keindahan yang kuat sehingga tidak puas dengan penampilan yang kosong atau sederhana, 5) menambah garisgaris, warna-warna, detil-detil (bagian-bagian) terhaadap gambarannya sendiri atau gambar orang lain.

d. Ketrampilan berpikir orisinal (originality): kemampuan memberikan respon unik yang berbeda dengan orang lain. Indikator orisinal (originality): 1) memikirkan masalah-masalah atau hal-hal yang tidak pernah dipikirkan oleh orang lain, 2) mempertanyakan cara-cara yang lama dan berusaha memikirkan cara-cara yang lama dan berusaha memikirkan cara-cara yang baru, 3)memilih a-simetri dalam menggambar atau membuat desain, 4) memiliki cara berpikir yang lain dari yang lain, 5) mencari pendekatan yang baru dari stereotif, 6) setelah membaca/mendengar gagasangagasan, bekerja untuk menemukan penyelesaian yang baru, 7) lebih senang 
mensintesis daripada menganalisis situasi.

e. Ketrampilan dalam menilai (evalution) : mencakup kemampuan menentukan patokan penilaian sendiri, mampu mengambil keputusan, mencetuskan dan melaksanakan gagasan.

Indikator menilai (evaluation): 1) memberikan pertimbangan atas dasar sudut pandangnya sendiri, 2) menentukan pendapat sendiri mengenai suatu hal, 3) menganalisis masalah atau penyelesaian secara kritis, 4) mempunyai alasan yang dapat dipertanggungjawabkan untuk mencapai suatu keputusan, 5) merancang suatu rencana kerja dari gagasan yang tercetus, 6) pada waktu tertentu tidak menghasilkan gagasan tetapi menjadi peneliti atau penilali yang kritis, 7) menentukan pendapat dan bertahan terhadapnya.

\section{Ciri-ciri afektif (non aptitude)}

a. Memiliki rasa ingin tahu, yaitu sifat untuk selalu terdorong untuk mengetahui lebih banyak, mengajukan banyak pertanyaan,

2. Pengembangan Kreativitas Anak Usia Dini dalam Keluarga

Anak usia dini merupakan anak yang berusia 0-6 tahun, yang berada pada tahap perkembangan awal masa anak-anak, memiliki karakteristik berpikir konkret, selalu memperhatikan orang, objek dan situasi, peka pengamatan dan ingin mengetahui atau meneliti.

b. Memiliki sifat imajinatif, yaitu sifat untuk mampu memperagakan atau membayangkan hal-hal yang tidak atau belum pernah terjadi, menggunakan khayalan tetapi mengetahui perbedaan antara khayalan dan kenyataan.

c. Memiliki rasa tertantang oleh kemajemukan yaitu sifat untuk selalu terdorong mengatasi masalah yang sulit, merasa tertantang oleh situasisituasi yang rumit, lebih tertarik pada tugas-tugas yang sulit.

d. Memiliki sifat berani mengambil resiko, yaitu sifat berani memberikan jawaban meskipun belum tentu benar, tidak takut gagal atau mendapat kritik, tidak ragu-ragu karena ketidakjelasan, hal-hal yang tidak konvensional atau kurang terstruktur.

e. Memiliki sifat menghargai yaitu sifat untuk dapat menghargai bimbingan dan pengarahan dalam hidup, menghargai kemampuan dan bakat-bakat sendiri yang sedang berkembang.

realistik, sederhana, animistik, egosentrik, dan memiliki daya imajinasi yang kaya. Menurut Hurlock (1980), masa anak-anak dimulai setelah bayi yang penuh dengan ketergantungan, yaitu kirakira usia 2 tahun sampai saat anak matang secara seksual, kira-kira 13 
tahun untuk wanita dan 14 tahun untuk laki-laki. Masa anak-anak dibagi lagi menjadi dua periode yang berbeda, yaitu awal dan akhir masa anak-anak. Periode awal berlangsung dari umur 2-6 tahun, dan periode akhir pada masa usia 6 tahun sampai saatnya anak matang secara seksual. Maka anak pada masa periode awal disebut sebagai anak usia dini.

Semua anak merupakan bagian dalam sebuah komunitas, seperti keluarga, sekolah, lingkungan rumah/masyarakat, atau pun club aktivitas lainnya (Craft, 2004: 264). Diantara berbagai lingkungan atau komunitas yang mengelilingi anak-anak, keluarga menjadi lingkungan pertama dan utama bagi anak dalam tumbuh dan kembangnya. Dalam mendidik anak agar tumbuh menjadi orang yang kreatif, tak lepas dari kontribusi orang tua dalam pendidikan kreativitas di keluarga.

Pengembangan kreativitas dalam keluarga bisa dimulai dengan memberikan kepercayaan kepada anak (Jeffrey dan Woods, 1997, dalam Craft, 2004). Suasana emosional yang baik antara orang tua dan anak akan memberikan kepercayaan diri dan rasa aman untuk anak, sehingga anak akan memiliki kesempatan untuk berkembang pada tingkat mereka sendiri (Shallcross, dalam Craft, 2004).

Fryer dan Collings (1991) mengartikan kreativitas sebagai imajinasi, originalitas, dan ekspresi diri. Dalam mengembangkan kreativitas kita perlu memerhatikan aspek dalam diri anak, yaitu akal, fisik dan perasaannya. Ketiga aspek tersebut perlu diberi stimulus melalui pengalaman-pengalaman belajar yang diberikan oleh orang tua kepada anak di rumah. Pengalaman belajar ini bisa diberikan melalui kegiatan bermain, baik di dalam rumah maupun di luar rumah, menggunakan alat permainan yang dibuat sendiri atau pun yang dibeli.

Bermain adalah dunia anak. Melalui kegiatan bermain, anak dapat melakukan aktivitas gerak tubuh, secara tidak sadar akan mencari inovasi atau pun jalan keluar sendiri, dan menumbuhkan emosi yang baik dalam diri anak. Olah fisik, akal, dan perasaan ini lah yang akan membangun kreativitas pada diri anak. Mariani (2008) menambahkan bahwa bermain bebas menjadi kunci pembuka bagi gudang-gudang bakat kreatif yang dimiliki setiap anak. Bermain menurut Mulyadi (2004), secara umum sering dikaitkan dengan kegiatan anak-anak yang dilakukan secara spontan. Terdapat lima pengertian bermain, yaitu:

a. Sesuatu yang menyenangkan dan memiliki nilai intrinsic pada anak

b. Tidak memiliki tujuan ekstrinsik, motivasinya lebih bersifat intrinsic 
c. Bersifat spontan dan sukarela, tidak ada unsur keterpaksaan dan bebas dipilih oleh anak

d. Melibatkan peran aktif keikutsertaan anak

e. Memiliki hubungan sistematik yang khusus dengan sesuatu yang bukan bermain, seperti kreativitas, pemecahan masalah, belajar bahasa, perkembangan social dan sebagainya.

Bagi anak usia dini, menambah "bumbu" dalam permainannya, menjadi indicator kreativitas anak tersebut. Kreativitas akan membuat kegiatan bermain menjadi menyenangkan, anak-anak akan merasa bahagia dan puas. Bermain memberikan keseempatan pada anak untuk mengekspresikan dorongan-dorongan kreatifnya sebagai kesempatan untuk merasakan obyek-obyek dan tantangan untuk menemukan sesuatu dengan cara-cara baru, untuk menemukan penggunaan suatu hal secara berbeda, menemukan hubungan yang baru antara sesuatu dengan sesuatu yang lain serta mengartikannya dalam banyak alternatif cara.Selain itu, bermain memberikan kesempatan pada individu untuk berpikir dan bertindak imajinatif, serta penuh daya khayal yang erat hubungannya dengan perkembangan kreativitas anak.

Berbagai bentuk kegiatan bermain yang dapat membantu mengembangkan kreativitas, antara lain mendongeng, bermain drama, menggambar, mewarnai, bermain alat music sederhana, bermain dengan plastisin, permainan dengan balok, berolah raga, dan berbagai permainan tradisional yang bisa diwariskan oleh orang tua kepada anaknya.

Hal yang perlu diperhatikan dan dibiasakan oleh orang tua dalam kegiatan bermain anak adalah pemberian rasa aman dan kebebasan. Rasa aman dan bebas secara psikologis merupakan kondisi yang penting bagi tumbuhnya kreativitas anak (Mariani, 2008, dan Craft, 2004). Rasa aman yang dimaksud adalah anak-anak diterima apa adanya, dihargai keunikannya, dan tidak teralalu cepat dievaluasi. Sedangkan kebebasan yang dimaksud adalah kebebasan untuk mengekspresikan gagasannya, sehingga anak dapat bereksperimen dengan gagasangagasan barunya baik yang menggunakan alat bermain atau tidak.

Keluarga harus bisa menjaga rasa aman dan kebebasan pada anak saat bermain sebagai upaya pengembangan kreativitas anak. Sekali anak merasa mampu menciptakan sesuatu yang baru dan unik, ia akan melakukan kembali pada situasi lain. Kreativitas memberi anak kesenangan dan kepuasan pribadi yang sangat besar. Penghargaan dari keluarga, baik orang tua maupun saudara-saudara lainnya, akan memberikan pengaruh nyata pada pengembangan kreativitasnya. 
Hal yang selanjutnya perlu dihindari oleh keluarga dalam pengembangan kreativitas anak, yaitu:

a. Menakut-nakuti atau mengancam anak. Banyak orang tua yang sering menakutnakuti atau mengancam anak jika anak tidak mau menurut. Jika hal tersebut dilakukan secara terus-menerus, secara tidak sadar, hal tersebut dapat menjadi pemicu ketakutan pada anak, sehingga tidak jarang anak menjadi penakut. Ketakutan pada anak dapat membuat kreativitas anak menurun.

b. Mengekang atau membatasi anak. Biarkan anak berkreasi sebebas mungkin selama masih dalam tahap yang wajar. Jika orang tua terlalu mengekang, over protectif, kebebasan anak untuk berkreasi menjadi terenggut.

Sedangkan hal-hal ini merupakan upaya orang tua untuk mengembangkan kreativitas anak, yaitu:

a. Bila seorang anak menunjukkan penemuannya, maka berilah pujian untuk memberikan semangat.

b. Latihlah anak untuk merencanakan aktivitas keluarga. Inisiatif anak harus dihargai supaya ada rasa jati diri yang positif.

c. Berikanlah kesempatan untuk bereksperimen dan dibuat kondusif agar bersikap positif terhadap lingkungan.

d. Orang tua membiasakan anakanak menghadapi tantangan dan rangsangan supaya kreatif dan jangan terlalu menuntun serta tidak ada ketegasan.

e. Anak supaya dilatih untuk berpikir kreatif dan solutif, contohnya jika anak tersesat di pusat perbelanjaan, bagaimana dan kemana harus meminta tolong.

f. Anak yang sedang asyik dengan pekerjaannya janganlah diganggu, karena konsentrasinya akan terganggu.

g. Orang tua harus memberi motivasi supaya anak dapat mengikuti atau melaksanakan idenya sendiri. Seringkali ide yang bagus dan baru, hilang karena tidak adanya kepercayaan diri sendiri atau tidak mampu mengendalikan diri.

h. Anak jangan diajari setiap langkah, tetapi sediakan ruang dibenaknya untuk membuat imajinasi berkembang, sehingga otaknya akan berfungsi dengan baik.

Pola pengasuhan dalam keluarga menjadi hal yang tak kalah penting dalam pengembangan kreativitas anak. Pola pengasuhan dalam keluarga dapat dikelompokkan menjadi tiga macam, yaitu otoriter, laizer faire, dan demokratis (Gerungan, 1991). Pola pengasuhan otoriter, orang tua 
biasanya bersikap dan berperilaku sangat keras. Orang tua sering sekali memberikan perintah dan atau larangan. Pola pengasuhan ini akan membuat anak takut, pasif dan kurang inisiatif. Hal ini diperkuat oleh Porter dan Hernacki (2001), bahwa umpan balik negative yang terus menerus sangat berbahaya bagi anak. Setelah beberapa tahun anak akan mengalami kemandekan belajar dan selanjutnya menghalangi pengalaman belajar mereka secara tidak sadar.

Pola Laizer-Faire, orang tua berada di tengah-tengah keluarga, tetapi tidak ada komunikasi dan tidak pernah mengambil inisiatif dalam kegiatan keluarga. Orang tua memberikan kebebasan penuh kepada anak-anak tanpa ada pengarahan dan pengendalian dari orang tua. Orang tua selalu mengikuti permintaan anak, hal ini memungkinkan orang tua tidak dihormati oleh anak-anaknya. Dalam keluarga yang demikian, sering muncul salah paham antar anggota keluarga, bahkan sering terjadi suatu pertentangan, sehingga misi pendidikan dalam keluarga tidak tercapai.

Pola demokratis, orang tua dituntut memiliki emosi yang stabil atau kematangan emosional, sehingga mampu menjelaskan suatu permasalahan yang timbul. Dalam keluarga orang tua sering berdiskusi dengan musyawarah untuk mencapai mufakat. Orang tua harus mampu menjelaskan alasan-alasan tentang peraturan yang ada dalam keluarga, sehingga anak menjadi paham. Dalam keluarga antara orang tua dan anak saling menghargai, jika terjadi penyimpangan yang dilakukan anak segera diberi tahu secepatnya. Sikap demokratis orang tua terhadap anakanaknya akan menyebabkan anakanak berani berinisiatif, tidak takut, lebih giat dan berani berkreasi yang akhirnya dapat mengembangkan kreativitas anak.

\section{PENUTUP}

Keluarga sebagai lingkungan pertama dan utama dalam proses tumbuh kembang anak, maka seluruh anggota keluarga, khususnya orang tua perlu memperhatikan aktivitas, perilaku, dan pola pengasuhan kepada anakanak jika ingin mengembangkan kreativitas anak. Pengembangan kreativitas dalam keluarga sangat penting karena akan membantu tumbuh kembang anak, baik pada aspek kognitif, bahasa, seni, fisik, dan moral anak.

\section{DAFTAR PUSTAKA}

Craft, A. (2004). Me-Refresh Imajinasi dan Kreativitas Anak-Anak. Depok: Cerdas Pustaka.

Fryer, M. and Collins, J.A. (1991). Teacher's view about Creativity, British Journal of Education Psychology, 61: 207-2019. 
Gerungan, W.A. (1991). Psikologis Sosial. Bandung: Eresto.

Hurlock, E. B. (1999). Perkembangan Anak Jilid 1 (Edisi 6). Jakarta: Erlangga.

Lestari, B. (2006). Upaya Orang Tua dalam Pengembangan Kreativitas Anak. Jurnal Ekonomi dan Pendidikan, Vol.3 No. 1, April 2006.

Mariani, D.A. (2008). Bermain dan Kreativitas pada Anak Usia Dini. Tersedia [Online]: https://deviarimariani.wordpres s.com/2008/06/12/bermaindan-kreativitas-anak-usia-dini/

Masnipal. (2013). Siap Menjadi Guru dan Pengelola PAUD Profesional. Jakarta: Elex Media Komputindo.

Miller, B. and Gerard, D. (1979). Family Influences on the Development of Creativity in Children: An Integrative Review. Journal .... Vol. 28, No.3 (Jul., 1979), pp 295312. Tersedia [Online]: https://www.jstor.org/stable/5 81942?seq=1\#page scan tab contents

Porter, B, D. and Hernacki, M. (2001). Quantum Teaching. Bandung: Kaifa.

Rothenberg, A. (2015). Family Backround, Creativity, and Genius. Tersedia [Online]: https://www.psychologytoday. com/blog/creativeexplorations/201511/familybackground-creativity-andgenius 